\title{
Mobile application of the Terminology Subset for Coping with Domestic Violence Against Children
}

\author{
Aplicativo móvel do Subconjunto Terminológico para o Enfrentamento da Violência Doméstica Contra a Criança \\ Aplicación móvil del Subconjunto Terminológico para Enfrentar la Violencia Doméstica contra los Niños
}

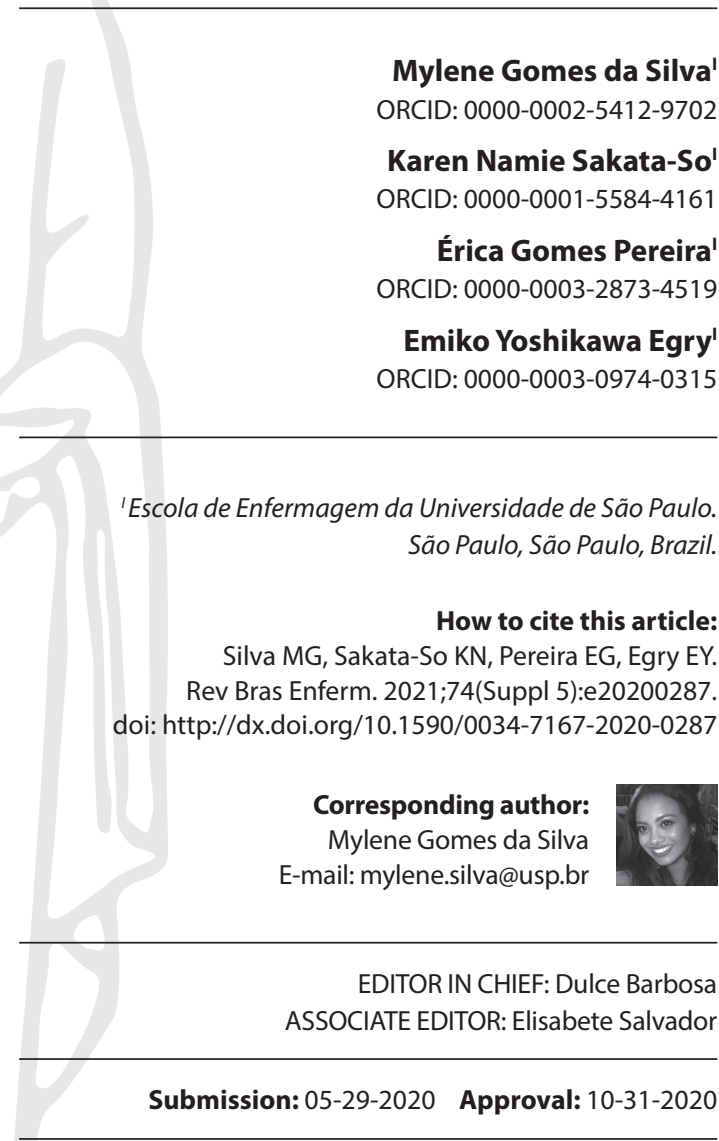

\begin{abstract}
Objective: to describe the development of a mobile application for the International Classification Terminology Subset for Nursing Practice for Coping with Domestic Violence Against Children. Methods: an applied research of technological development, based on the Analysis, Design, Development, Implementation and Evaluation model and on the terminological subset based on the Theory of Nursing Praxis Intervention in Collective Health framework. Results: the application is divided into: 1) "Definition": characterizes the phenomenon of violence against children; 2) "Assistance": electronic record of nursing care; 3) "Diagnosis Consultation"; 4) "Intervention Consultation": nursing diagnoses, outcomes, and interventions related to children and their families, subdivided into Strengthening and Weariness group. Final considerations: built from scientific research, the application has the potential to support nursing care, presenting, in an organized and systematic manner, nursing diagnoses, outcomes, and interventions, in addition to enabling the registration of cases under monitoring.
\end{abstract}

Descriptors: Child Abuse; Primary Health Care; Mobile Applications; Nursing Diagnosis; Nursing Informatics.

\section{RESUMO}

Objetivo: descrever o desenvolvimento do aplicativo móvel para o Subconjunto Terminológico da Classificação Internacional para a Prática de Enfermagem para o Enfrentamento da Violência Doméstica Contra a Criança. Métodos: pesquisa aplicada de desenvolvimento tecnológico, fundamentada no modelo Analysis, Design, Development, Implementation and Evaluation e no subconjunto terminológico embasado no referencial da Teoria de Intervenção Práxica da Enfermagem em Saúde Coletiva. Resultados: o aplicativo divide-se em: 1) "Definição": caracteriza o fenômeno da violência contra crianças; 2) "Atendimentos": registro eletrônico do atendimento de enfermagem; 3) "Consultar Diagnósticos"; 4) "Consultar Intervenções": diagnósticos, resultados e intervenções de enfermagem referentes à criança e à família, subdivididos nos grupos de Fortalecimentos ou Desgastes. Considerações finais: construído a partir de uma pesquisa científica, o aplicativo tem o potencial de apoiar o atendimento das enfermeiras, apresentando, de forma organizada e sistematizada, os diagnósticos, resultados e intervenções de enfermagem, além de possibilitar o registro dos casos em acompanhamento. Descritores: Maus-Tratos Infantis; Atenção Primária à Saúde; Aplicativos Móveis; Diagnósticos de Enfermagem; Informática em Enfermagem.

\section{RESUMEN}

Objetivo: describir el desarrollo de la aplicación móvil para el Subconjunto Terminológico de la Clasificación Internacional de Prácticas de Enfermería para Enfrentar la Violencia Doméstica contra los Niños. Métodos: investigación de desarrollo tecnológico aplicado, basado en el modelo Analysis, Design, Development, Implementation and Evaluation y en el subconjunto terminológico basado en el marco de la Teoría de la Intervención Práxica en Enfermería en Salud Pública. Resultados: la aplicación se divide en: 1) “Definición”: caracteriza el fenómeno de la violencia contra los niños; 2) "Asistencia": registro electrónico de cuidados de enfermería; 3) "Consultar Diagnósticos"; 4) "Consultar Intervenciones": diagnósticos, resultados e intervenciones de enfermería referidas al niño y la familia, subdivididas en grupos de Fortalecimiento/Desgaste. Consideraciones finales: construida a partir de la investigación científica, la aplicación tiene el potencial de apoyar la atención de las enfermeras, presentando de manera organizada y sistemática los diagnósticos, resultados e intervenciones de enfermería, además de posibilitar el registro de los casos en seguimiento. Descriptores: Maltrato a los Niños; Atención Primaria de Salud; Aplicaciones Móviles; Diagnóstico de Enfermería; Informática Aplicada a la Enfermería. 


\section{INTRODUCTION}

Domestic violence against children impacts on interpersonal relationships and family spaces, causing serious consequences for child development and compromising family relationships. Children who are victims of violence carry the physical and psychological marks of violence suffered until adult life, with losses in their self-esteem, ability to resolve conflicts, respect and tolerance, and this can give the phenomenon a cyclical character ${ }^{(1-2)}$.

Worldwide, in 2015, about 300 million children between 2 and 4 years old were victims of disciplinary violence (physical or psychological) perpetrated by their caregivers, and 250 million suffered physical punishment ${ }^{(3)}$.

In Brazil, in 2013, 188,624 cases of violence were reported, $29,784(15.8 \%)$ in the $0-9$ age group. Home was the main place of violence, accounting for $58.8 \%$ of all cases $^{(4)}$.

Between 2011 and 2017, 219,717 cases of violence against children were recorded, and in its most brutal form, sexual violence accounted for $31.5 \%(n=58,037)$ of the total cases reported for this type of violence $(n=184,524)$ in the same period ${ }^{(5)}$.

Coping with domestic violence against children goes beyond the actions to be taken by the health sector. However, the performance of this sector is fundamental ${ }^{(6-7)}$, including actions performed in Primary Health Care (PHC), such as those performed by nurses.

In this regard, we thought about building an application that could support nurses, especially within PHC, given the longitudinal character of the care developed at this level of care. Therefore, the application was designed as a support tool to systematize the care provided by nurses, enabling case registration and monitoring and continuous assessment of nursing diagnoses, outcomes, and interventions (ND, NO, and NI).

Using mobile technologies is a reality that is increasingly present in people's lives, and its advancement has been encouraging the design of a new performance also in the health field (e-Health). Using mobile devices by health professionals and services is known as Mobile Health ( $\mathrm{m}$-Health) and is configured as a form of assistance that provides, among other possibilities, diagnostic support, schedule management and monitoring of people's health parameters ${ }^{(8-9)}$.

In this context, mobile devices and applications have been used in the most diverse health fields, such as nursing, integrating actions with a logical structure for data, information, and knowledge production. All these technologies can serve to support nurses' work process and decision-making ${ }^{(10)}$.

"CIPE Violência" was conceived from the development and validation in Brazil of the International Classification for Nursing Practice (ICNP ${ }^{\circ}$ ) Terminology Subset for Coping with Domestic Violence Against Children, from the perspective of public health. This Terminology subset was developed by Albuquerque in 2014, and validated by Sakata-So in 2018. In total, the Terminology Subset contains $60 \mathrm{ND} / \mathrm{NO}$ and $100 \mathrm{NI}$, of which: 14 ND/NO from Strengthening and Promotion ( 9 relating to children and 5 relating to their families) and 46 from Weariness, Causes, Manifestations and Consequences ( 30 related to children and 16 related to their families). As for NI, there are 19 in Strengthening and Promotion, 63 are in Weariness, Causes, Manifestations and Consequences and 18 were applicable to both groups ${ }^{(11-12)}$.
Unlike other theoretical frameworks adopted for the production of ICNP' terminology subsets, this was built based on the theoretical and methodological framework of the Theory of Nursing Praxis Intervention in Collective Health (TIPESC), with emphasis on the sociological categories of gender and generation ${ }^{(13-14)}$.

In this way, the ICNP ${ }^{\circ}$ Terminology Subset for Coping with Domestic Violence Against Children, which makes up the application content, is aligned with public health knowledge, with an emphasis on coping with violence against children, not only focusing on injuries, but also in preventing violence and promoting emancipatory actions by subjects ${ }^{(12)}$.

Therefore, this research is justified by the impacts caused by violence in children's and their families'lives and by the possibility of disseminating the ICNP ${ }^{\circ}$ Terminology Subset for Coping with Domestic Violence Against Children as a potential support tool for the work process of $\mathrm{PHC}$ nurses in actions to cope with this violence.

\section{OBJECTIVE}

To describe the development of a mobile application for the International Classification Terminology Subset of the for Nursing Practice for Coping with Domestic Violence Against Children.

\section{METHODS}

\section{Ethical aspects}

This study was not submitted to a Research Ethics Committee, as it involves the development of a technology that did not involve the participation of human beings as research subjects.

\section{Type of study}

This is an applied research of technological production for the development of a multimedia application for mobile devices.

\section{Methodological procedures}

This study is the result of a survey by the Institutional Scholarship Program for Initiation in Technological Development and Innovation of the Brazilian National Council for Scientific and Technological Development (PIBITI (Programa Institucional de Bolsas de Iniciação em Desenvolvimento Tecnológico e Inovação)/CNPq (Conselho Nacional de Desenvolvimento Científico e Tecnológico)), which was developed between August 2018 and July 2019.

To develop the application "CIPE Violência", firstly, applications in Brazilian Portuguese were investigated in virtual stores with the words "nursing diagnosis". Three applications were found related to the theme and which are described in Chart 1.

It was observed that no application featured clinical support for nurses to deal with violence against children. All of them had as main focus the description of the constituent elements of the diagnoses and prescriptions in nursing used by North American Nursing Diagnosis Association (NANDA) taxonomy.

After researching virtual stores, the ADDIE model (Analysis, Design, Development, Implementation and Evaluation) was used for application development ${ }^{(15)}$. Four of the five phases foreseen by the model were used: Analysis, Design, Development and Implementation. The fifth phase, Evaluation, should comprise further studies. 
Chart 1 - Applications focused on nursing diagnoses, São Paulo, São Paulo, Brazil, 2018

\begin{tabular}{|c|c|c|c|l|c|}
\hline Application & Platform & Language & Size & Focus & Copyright \\
\hline $\begin{array}{c}\text { Diane: Diagnósticos e prescrições } \\
\text { de Enfermagem }\end{array}$ & Android & $\begin{array}{c}\text { Brazilian } \\
\text { Portuguese }\end{array}$ & $14 \mathrm{MB}$ & $\begin{array}{l}\text { NANDA taxonomy 2015-2017 for generic } \\
\text { nurse support in the nursing process. }\end{array}$ & Paid - Lans \\
\hline $\begin{array}{c}\text { Diagnósticos de Enfermagem } \\
\text { da NANDA }\end{array}$ & iOS/Android & $\begin{array}{c}\text { Brazilian } \\
\text { Portuguese }\end{array}$ & $104.8 \mathrm{MB}$ & $\begin{array}{l}\text { NANDA taxonomy 2015-2017 for generic } \\
\text { nurse support in the nursing process. }\end{array}$ & $\begin{array}{c}\text { Paid - Artmed } \\
\text { Publishing House }\end{array}$ \\
\hline Enfermeiro Diagnosticador & iOS/Android & $\begin{array}{c}\text { Brazilian } \\
\text { Portuguese }\end{array}$ & $10.2 \mathrm{MB}$ & $\begin{array}{l}\text { Practical exercises for students to build nursing } \\
\text { diagnoses in scenarios about cardiac surgery, } \\
\text { hypertension, and chronic kidney disease. }\end{array}$ & $\begin{array}{c}\text { Free - Jéssica } \\
\text { Dantas Sá }\end{array}$ \\
\hline
\end{tabular}

After defining the application's name, "CIPE" Violência", the scientific content selection, the construction of screen mockup and the definition of a technological company that would develop the tool were carried out.

The following is a description of each of the phases:

1. Analysis: search for applications on nursing diagnoses and classification in Play Store (Android, Google) and App Store (iOS, Apple) operating systems. Definition of the name ("CIPE Violência"), target audience (nurses, especially those working in $\mathrm{PHC}$ ) and self-instructional characteristics (tool to support the work process, containing ND, NO, and NI to cope with domestic violence against children).

2. Design: content selection and storyboard elaboration using Knowles' theory of andragogy ${ }^{(16)}$ and the ICNP ${ }^{\circ}$ Terminology Subset for Coping with Domestic Violence Against Children. Knowles' theory of andragogy, as the target audience of "CIPE Violência" would be adult responsible for their own learning, using an application to assist in the understanding of a problem situation during a clinical care of nurses;

3. Development: interface design and selection of technologies for application development, navigation structure and environment planning (HTML, CSS, and JavaScript). The study authors designed the desired interface for the application on PowerPoint ${ }^{\oplus}$ screens, developing a mockup, which was delivered to the hired team of developers who followed up on the technical development steps;

4. Implementation: from mockup, the team of developers shared a prototype of the application built on a web tool, being accessed from a link for preview by the creator team. From that moment on, it was possible to discuss improvements in the flow of screens and in the order of content presentation, aiming to make the content available in an intuitive way and to improve user-application interaction. Through meetings between the teams, it was possible to adjust the prototype for the final version according to what had been initially designed, adapting it to the difficulties that arose. One of the difficulties that is worth highlighting was the extensive content of the Terminology Subset to be transposed into an application. The alternative chosen was to keep the statements in full, placing them in text boxes that expand when they are clicked.

The computational language application was produced by the Applied Information Technology Laboratory (LTIA - Laboratório de Tecnologia da Informação Aplicada) at Universidade Estadual Paulista (UNESP).

\section{Data analysis}

The results were organized in a descriptive and illustrative way in order to better represent the technological product, the application content and its functionalities.

\section{RESULTS}

"CIPE Violência", being a product resulting from scientific research, provides reliable and scientifically validated content. It was produced by nurse researchers who studied ICNP ${ }^{\circ}$ terminology subsets and the phenomenon of violence against children. The Terminology Subset was validated by nurses who had experience with nursing classification and/or domestic violence against children in the context of care, teaching, research and/or management.

The application is hosted on UNESP servers, with free access through profile registration. It is in Brazilian Portuguese, available for download in Play Store https://play.google.com/store/apps/ details?id=cipeViolencia.Itia\&hl=pt_BR and App Store https:// apps.apple.com/br/app/cipe-violence/id1482577896? I=en, with the possibility of offline use and size of $46.2 \mathrm{MB}$.

A simple search with keywords that relate to the topic, such as "child violence" or "nursing diagnosis", will allow users to find the application easily. In total, the application "CIPE Violencia" contains 16 screens.

When installing the application on a mobile device and clicking on the icon to start using it, a "welcome" screen will appear, containing access fields and user account, which is done through email and password or there is still the possibility of creating a new register (Figure 1). When creating an account, there are fields to be filled in with name, sex, date of birth, state, municipality, professional training, field of expertise, if the user has professional experience with domestic violence against children, if the user has professional experience with Nursing Classifications, email, password, and password confirmation. The fields selected to compose the user profile were based on those used in the research by Sakata-So ${ }^{(12)}$, in order to characterize the profile of expert judges who assessed the ICNP ${ }^{\circ} \mathrm{ND}, \mathrm{NO}$, and $\mathrm{NI}$ for Coping Terminology Subset with Domestic Violence Against Children. This information can be potent for purposes of comparison between the profile of the research subjects who assessed NDs, NOs, and $\mathrm{Nls}$ and those who are their real users. In conjunction with other information, such as user ratings and comments on the application, it is possible to generate parameters for the creation and development team to make improvements, such as the need to adapt the content or submit it to other forms of validation. 
The main page includes four axes (Figure 1):

1. "Definition": when selecting this option, a brief definition about violence against children will appear, in order to contextualize the target audience about the theme relevance and its approach in nurses' clinical assistance;

2. "Assistance": after the click, a screen will open with the option to create a new assistance, as well as a list of cases already registered, so that the consultation can be accessed again or the previously selected NDs and Nis can be added and/or changed. When choosing to describe assistance, the requested data are: identification of the index case (it is suggested to use only the initials of the name), date of birth and sex. An annotation field will be available if the user needs to add any other information;

3. "Diagnosis Consultation": in this option, the user will be able to select whether a ND to be searched for refer to "Child" or "Family". On the next screen, a list with NDs will appear, in which the user can choose those belonging to Strengthening or Weariness;

4. "Intervention Consultation": after the click, nurses select a NI that apply to the ND/NO previously chosen. To select both $\mathrm{ND}, \mathrm{NO}$, and $\mathrm{NI}$, the user only needs to click on the star icons in front of the sentences (those selected will appear first in the list). After completing $\mathrm{NI}$ selection, the user finalizes and saves the records that will remain archived in the system.

"Diagnosis Consultation" and "Intervention Consultation" axes can be used in two ways: a) Visualization of the complete Terminology Subset, allowing nurses to use the application in order to obtain information/consultation about content, without necessarily creating assistance; b) Visualization of NDs, NOs, and NIs related to the cases created by nurses, seeking them within the assistance registered in the "Assistance" axis. NDs and NIs related to each case assisted will be marked with the star icon highlighted to the left of the statement and will always be shown first in the list (Figure 2).

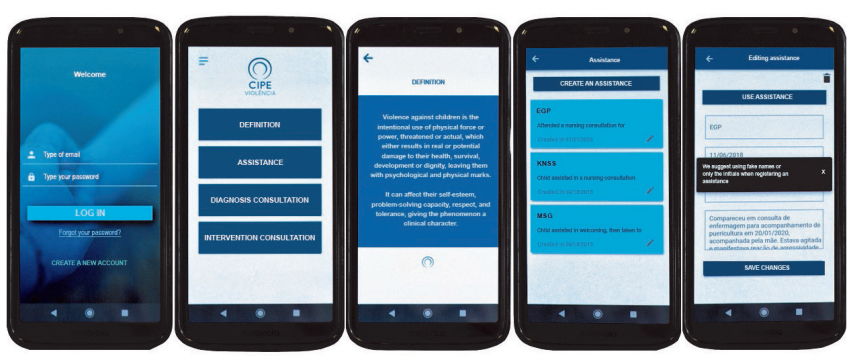

Figure 1 - Illustrative image of the opening screen, main screen and "Definition" and "Assistance" axes

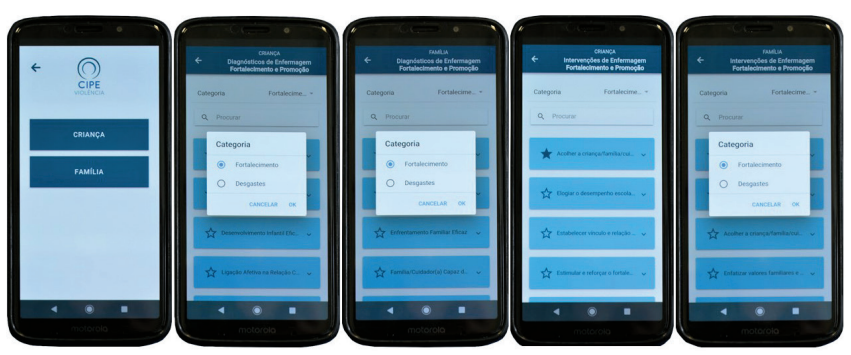

Figure 2 - Illustrative image of "Diagnosis Consultation" and "Intervention Consultation" screens
As additional information, the "Menu" button will be present on all screens in the upper left corner with the following options: "Profile"; "References"; "Child and Support"; "How to use"; "Exit". In the "References" option, all references used to prepare the application content will appear with their respective links, if available on the internet for access.

\section{DISCUSSION}

"CIPE Violência" has the potential to support the systematization of $\mathrm{PHC}$ nurses' assistance in dealing with violence against children. ND, $\mathrm{NO}$, and $\mathrm{NI}$ were built from two other studies that are in line with the precepts of public health and that consider violence as a social phenomenon, whose coping is possible based on the dialectical concept of the health-disease process ${ }^{(11-12)}$. The role of nurses in $\mathrm{PHC}$ requires a continuous and longitudinal monitoring of their actions, contextualized from the family and the territory. TIPESC, the theory on which the application content was based, awakens a critical interpretation of social phenomena for the construction of systematic interventions in the objective reality of individuals, families and social groups.

In the case of violence against a specific generational group - children - and the domestic environment in which it occurs, it is worth mentioning the sociological categories generation and gender, which serve as a background for analysis of violence against children, as the relationships and family are permeated by inequalities of power, including those of gender and generation ${ }^{(17)}$.

The gender category can be defined as a constitutive element of social relations based on the perceived differences between sexes, in the socialization processes of men and women. It allows to understand the social constructions of femininity and masculinity, socially determined for men and women. Gender analysis reveals unequal conditions for the exercise of power, in which women in general occupy subordinate and secondary positions in relation to men ${ }^{(13,17)}$.

The generation category is the one that defines the place occupied by childhood in society, therefore, the element that underlies the field of childhood sociology. Thus, it admits to seeing that children are participants in society; therefore, they will have demands to be met and that public policies, of development and economy, must consider the perspective of their impact on children. Childhood is not a transition phase, but a social category with rights that must be highlighted and respected by other generational categories ${ }^{(13,18)}$.

Based on the possibility of contributing to the systematization of nursing care in coping with child victims of violence and taking advantage of the growing technological evolution in the health field, it was considered that creating the application " $C I P E$ Violência" could help nurses' work process, for allowing, in the same application, access to content related to ND, NO, and NI to cope with violence and record their decisions at each service provided.

Mobile devices are in place in many aspects of life, offering instant information for everyday tasks. In the health field, they are constantly expanding, being developed for professionals or patients, in which they can be handled to inform, instruct, record, guide, alert, remember or communicate. Technological advances have increasingly impacted daily health practices, and in this context, nurses' daily lives have also been greatly influenced by technology ${ }^{(19)}$.

Applications focused on the health field have several functions, such as data organization, information storage, diagnostic support, 
support in the training of professionals and mutual sharing of information by users, professionals, students and/or professors. In addition to disseminating the knowledge produced in health and nursing, these technologies contribute to disseminate information related to health issues, illness, prevention, promotion, and health education ${ }^{(10,20)}$.

Technological resources have been increasingly incorporated into the work of nurses, but the adaptation of a digital technological resource in the work process can encounter several limitations and one of them is familiarity with the process of computerization of resources ${ }^{(9,21)}$.

On the other hand, there are facilities for mobile devices, which are related to utility, ease of handling and interoperability with other users and/or devices. As for applications, they need to be intuitive and quick to learn, and, in nurses' work process, they must be a tool that facilitates the systematization and access to information and not one more step to be accomplished in the dynamics of a work, which is already so overwhelmed ${ }^{(9-10,21)}$.

"CIPE Violência" took into account aspects such as being easy to navigate, providing quick content consultation and enabling registration of the most relevant information of cases that nurses are assisting.

In addition to use by nurses, the application has the potential to be used by nursing students. By adding a set of NDs, NOs, and NIs related to the fight against domestic violence against children, the application can be used in the context of training as a pedagogical tool to present the Terminology Subset content and foster clinical thinking practice from ICNP'. It is a tool that can be explored in case studies or simulations of a real care situation, instigating more totalizing perspectives on the social phenomenon of violence.

Implementing mobile devices in the teaching-learning process in nursing education has also been used to complement studies, enabling conversations, sharing information and knowledge between students and professors, regardless of geographical distance ${ }^{(20,22)}$. The strengths of using mobile devices in the teaching-learning process of nursing include the possibility of maintaining interaction between students and professors, including those from other health fields. It also has the potential to bring what is being taught closer to professional clinical practice. However, it is necessary to pay attention to the need to have well-established infrastructure and institutional policies to use this type of technological tool, in addition to having specific training and ongoing support so that users can fully understand all the functions of the device and the application to be used ${ }^{(22)}$.

In general, the application "CIPE Violência" was built supported by scientific productions that supported the content, the type of use by the target audience and its potential for applicability as a support tool for nurses in $\mathrm{PHC}$ or even in a training context.

Furthermore, it constitutes a basis for the nomenclature of nursing in $\mathrm{PHC}$ regarding coping with domestic violence against children, which can be used to show evidence of good nursing practices and discover and build ways of intervention that can bring indicators of change in epidemiological profiles.

In order to develop an application in the health field, it is important to follow defined and well-structured steps and to have supported scientific research, groups of professionals and/ or services and health institutions (20,23-24). $^{2}$.

It is worth mentioning that, even if well-defined and structured steps have been followed, the real potential for using this type of technological product depends on conditions that go far beyond the simple availability of technology to health professionals. There is a need for working conditions, guarantee of rights, adequate time for assistance and strengthening of the care network. Therefore, the authors do not intend that the application "CIPE Violência" accounts for all the complexity that the phenomenon of violence means. It represents only a small contribution to the chain of actions that cope with domestic violence against children needs.

\section{Study limitations}

The application content is available exclusively in Brazilian Portuguese, and includes part of the nursing process that is used by the nurse, especially ND, NO, and NI during consultations to cope with violence against children. Moreover, future studies are needed to validate the use of the application in nurses' daily work, completing the fifth phase of the ADDIE method, validation.

\section{Contributions to nursing}

The application "CIPE Violência" supports nurses' clinical care, particularly in the assistance of suspected or confirmed cases of violence against children. It can also be used by nursing students to approach one of the possible systems of nursing classification, the social phenomenon of violence and its ways of coping.

\section{FINAL CONSIDERATIONS}

It is expected that the stage presentation and description of "CIPE Violência" development can instigate the formulation of other applications based on scientific research, which gives rigor and greater reliability in the content to be accessed and disseminated.

The content of "CIPE Violência" is based on an ICNP" terminology subset constructed from a theoretical framework of nursing in public health, which awakens a questioning and critical posture of social phenomena for a constant process of unveiling its essence and think of ways for overcoming.

When used by nurses and/or nursing students, the application "CIPE Violência" can contribute, in a more accurate way, to the role of nurses in coping with violence against children and also to the dissemination of scientific knowledge produced by nurses.

Constructed from scientific research, the application has the potential to support nursing care as it presents the specific content of an ICNP ${ }^{\circ}$ terminology subset in an organized and systematized manner, also making it possible to register the cases being monitored by nurses in $\mathrm{PHC}$.

\section{FUNDING}

This study received financial support from CNPq's PIBITI for granting a scholarship to the first author in 2018/2019.

\section{ACKNOWLEDGMENTS}

We would like to thank CNPq, for the Senior Productivity Scholarship and the Scientific Initiation Scholarship granted, and to UNESP's LTIA, for the application technological development. 


\section{REFERENCES}

1. Fornari LF, Sakata-So KN, Egry EY, Fonseca RMGS. Gender and generation perspectives in the narratives of sexually abused women in childhood. Rev Latino-Am Enfermagem. 2018;26:e3078. doi: 10.1590/1518-8345.2771.3078

2. Sakata-So KN, Egry EY, Apostólico MR, Wazima CM. Can institutional videos contribute towards the debate on how to deal with domestic violence against children? Ciênc Saúde Coletiva. 2016;21(8):2347-56. doi: 10.1590/1413-81232015218.04592016

3. United Nations Children's Fund. A familiar face: violence in the lives of children and adolescents. [Internet]. New York: UNICEF. 2017 [cited 2020 Apr 7]. Available from: https://www.unicef.org/publications/files/Violence_in_the_lives_of_children_and_adolescents.pdf

4. Ministério da Saúde (BR). Secretaria de Vigilância em Saúde. Departamento de Vigilância de Doenças e Agravos Não Transmissíveis e Promoção da Saúde. Viva: vigilância de violência e acidentes: 2013 e 2014[Internet]. Brasília: Ministério da Saúde. 2017 [cited 2020 Apr 7]. Available from: https://bvsms.saude.gov.br/bvs/publicacoes/viva_vigilancia_violencia_acidentes_2013_2014.pdf

5. Ministério da Saúde (BR). Secretaria de Vigilância em Saúde. Análise epidemiológica da violência sexual contra crianças e adolescentes no Brasil, 2011 a 2017 [Internet]. 2018 [cited 2020 Apr 7]. Available from: https://www.saude.gov.br/images/pdf/2018/junho/25/2018-024.pdf

6. Apostólico MR, Egry EY, Fornari LF, Gessner R. Accuracy of nursing diagnoses for identifying domestic violence against children. Rev Esc Enferm USP. 2017;51:e03290. doi: 10.1590/s1980-220x2017019103290

7. Vieira LJES, Oliveira AKA, Moreira DP, Pereira AS, Catrib AMF, Lira SVG. Reports from social assistance, education and public security managers in coping violence. Cad Saúde Colet. 2015;23(3):231-8. doi:10.1590/1414-462X201500030118

8. Banos O, Villalonga C, Garcia R, Saez A, Damas M, Holgado-Terriza JA, et al. Design, implementation and validation of a novel open framework for agile development of mobile health applications. Biomed Eng. 2015;14(Suppl 2):S6. doi: 10.1186/1475-925X-14-S2-S6

9. Gagnon MP, Ngangue P, Payne-Gagnon J, Desmartis M. m-Health adoption by healthcare professionals: a systematic review. Jamia. 2015;23(1):212-20. doi: 10.1093/jamia/ocv052

10. Silva AMA, Mascarenhas VHA, Araújo SNM, Machado RS, Santos AMR, Andrade EMLR. Mobile technologies in the nursing area. Rev Bras Enferm. 2018;71(5):2570-78. doi: 10.1590/0034-7167-2017-0513

11. Albuquerque LM, Carvalho CMG, Apostólico MR, Sakata KN, Cubas MR, Egry EY. Nursing terminology defines domestic violence against children and adolescents. Rev Bras Enferm. 2015;68(3):393-400. doi: 10.1590/0034-7167.2015680311i

12. Sakata-So KN, Silva MG, Egry EY, Cubas MR, Albuquerque LM. Subconjunto terminológico para o enfrentamento da violência doméstica contra a criança: um estudo de validação. Atas Investig Qualit Saúde [Internet]. 2019 [cited 2020 Apr 7];(2):1000-09. Available from: https:// proceedings.ciaiq.org/index.php/CIAIQ2019/article/view/2174

13. Egry EY, Fonseca RMGS, Oliveira MAC. Science, public health and nursing: highlighting the gender and generation categories in the episteme of praxis. Rev Bras Enferm. 2013;66(spe):119-33. doi: 10.1590/S0034-71672013000700016

14. Egry EY. Saúde Coletiva: construindo um novo método em enfermagem. São Paulo: Ícone; 1996.

15. Almonen RK, Kaufman D, Alotaibi H, Al-Rowais NA, Albeik M, Albattal SM. Applying the ADDIE - Analysis, Design, Development, Implementation and Evaluation: instructional design model to continuing professional development for primary care physicians in Saudi Arabia. Int J Clin Med. 2016;07(08):538-46. doi: 10.4236/ijcm.2016.78059

16. Barros R. Revisiting Knowles and Freire: andragogy versus pedagogy - or the dialogic as the essence of socio-pedagogic mediation. Educ Pesqui. 2018;44:e173244. doi: 10.1590/S1678-4634201844173244

17. Egry EY, Apostólico MR, Albuquerque LM, Gessner R, Fonseca RMGS. Understanding child neglect in a gender context: a study performed in a Brazilian city. Rev Esc Enferm USP. 2015;49(4):555-62. doi: 10.1590/S0080-623420150000400004

18. Qvortrup J. Nine theses about "childhood as a social phenomenon". Pro-posições. 2011;22(1):199-211. doi: 10.1590/S0103-73072011000100015

19. Mamta. Nursing informatics: the future now. Nurs J India [Internet]. 2014 [cited 2020 Apr 7];105(5):198-9. Available from: https://www.ncbi. nlm.nih.gov/pubmed/25924417

20. Mota NP, Vieira CMA, Nascimento MNR, Bezerra AM, Quirino GS, Félix NDC. Mobile application for the teaching of the International Classification for Nursing Practice. Rev Bras Enferm. 2019;72(4):1020-7. doi: 10.1590/0034-7167-2018-0751

21. Rezende LCM, Santos SR, Medeiros AL. Assessment of a prototype for the Systemization of Nursing Care on a mobile device. Rev Latino-Am Enfermagem. 2016;24:e2714. doi: 10.1590/1518-8345.0898.2714

22. Lall P, Rees R, Law GCY, Dunleavy G, Cotič Ž, Car J. Influences on the implementation of mobile learning for medical and nursing education: qualitative systematic review by the digital health education collaboration. J Med Internet Res. 2019;21(2):e12895. doi: 10.2196/12895

23. Gomes MLS, Rodrigues IR, Moura NS, Bezerra KC, Lopes BB, Teixeira JJD, et al. Evaluation of mobile apps for health promotion of pregnant women with preeclampsia. Acta Paul Enferm. 2019;32(3):275-81. doi: 10.1590/1982-0194201900038

24. Barra DCC, Paim SMS, Sasso GTMD, Colla GW. Methods for developing mobile apps in health: an integrative review of the literature. Texto Contexto Enferm. 2017;26(4):e2260017. doi: 10.1590/0104-07072017002260017 